\title{
In vitro sensitivity of B-cell chronic lymphocytic leukemia to cladribine and its combinations with mafosfamide and/or mitoxantrone
}

\author{
AGNIESZKA KOBYLINSKA ${ }^{1,4}$, JOLANTA BEDNAREK ${ }^{1}$, JERZY Z. BLONSKI ${ }^{2}$, MALGORZATA HANAUSEK $^{3}$, \\ ZBIGNIEW WALASZEK ${ }^{3}$, TADEUSZ ROBAK ${ }^{2}$ and ZOFIA M. KILIANSKA ${ }^{1}$ \\ ${ }^{1}$ Department of Cytobiochemistry, University of Lodz; ${ }^{2}$ Department of Hematology, Medical University of Lodz, \\ Poland; ${ }^{3}$ Department of Pharmacology, University of Texas Health Science Center, San Antonio, TX, USA
}

Received June 6, 2006; Accepted August 29, 2006

\begin{abstract}
We examined in vitro sensitivity of B-CLL cells exposed to cladribine, mafosfamide, mitoxantrone and combinations of cladribine with mafosfamide and/or mitoxantrone. The results revealed that each applied treatment of leukemic cells, besides having a cytotoxic effect, affected the events associated with apoptosis. All drugs used alone, and cladribine combinations with mafosfamide and/or mitoxantrone induced DNA fragmentation and the changes in expression/proteolysis level of caspase-3, caspase-9 precursors, PARP-1, lamin B, Bax and Bcl-2; however, each to a different degree. The exposure of leukemic cells to both cladribine combinations induced stronger effects. Moreover, the data showed that the expression of regulatory antiapoptotic protein $\mathrm{Bcl}-2$ generally decreased in drug-treated B-CLL cells, whereas proapoptotic polypeptide Bax increased, resulting in enhancement of Bax-Bcl-2 ratios in comparison with untreated cells. Drug-treatment of the studied cells induced the translocation of Bax protein from the cytosol to the cellular pellet, containing mitochondria, where this polypeptide indicated the capacity for oligomerization. These observations suggest that the examined drugs are able to induce apoptosis of B-CLL cells via the mitochondria pathway.
\end{abstract}

\section{Introduction}

B-cell chronic lymphocytic leukemia (B-CLL) is a hematological neoplasm characterized by sustained lymphocytosis in peripheral blood with apparently mature lymphocytes

Correspondence to: Dr Zofia M. Kilianska, Department of Cytobiochemistry, University of Lodz, Banacha 12/16, 90-237 Lodz, Poland

E-mail: zkilian@biol.uni.lodz.pl

Present address: ${ }^{4}$ Institute of Occupational Medicine, Lodz, Poland

Key words: B-cell chronic lymphocytic leukemia, in vitro, chemosensitivity, apoptosis-related events which have been arrested at an early stage of differentiation. Leukemic cells are believed to accumulate primarily due to defects in apoptosis rather than uncontrolled proliferative capacity, and this model is supported by the observation that most B-CLL cells are arrested in the $\mathrm{G}_{0}$ phase of the cell cycle and characterized by prolonged survival in vivo (1-3). New insights into pathophysiology and the prognostic parameters of B-CLL are beginning to change the treatment of this disease. In the past B-CLL patients were cured with alkylating agents alone or administered in combinations with corticosteroids, but numerous clinical data suggest that higher remission rate can be obtained when purine analogs are employed as first therapy (4-6). Two purine analogs, i.e. cladribine (2-chloro-2'-deoxyadenosine; 2-CdA) and fludarabine (9- $\beta$-D-arabinosyl-2-fluoroadenine-5'-monophosphate) have indicated pronounced antitumor activity (7-9). Among the proposed mechanisms are a direct interference with DNA and RNA biosynthesis, DNA repair, induction of apoptosis in leukemic cells, cell cycle control, or signal transduction pathways $(8,10,11)$. A number of studies have investigated the use of cladribine or fludarabine in monotherapy or in combinations with different drugs such as alkylating agents, glucocorticoids, and anthracyclines (12-15).

The purpose of this study was to assess in vitro chemosensitivity of B-CLL cells to cladribine and its combinations with mafosfamide (the active form of cyclophosphamide in vitro) or mafosfamide + mitoxantrone and to gain insight into the changes caused by this $\operatorname{drug}(\mathrm{s})$ on expression/ proteolysis of several apoptosis-related proteins, proapoptotic protein Bax translocation, its oligomerization as well as fragmentation of DNA. The in vitro combinations of cladribine (C) with mafosfamide (CMf) or mafosfamide + mitoxantrone (CMfM) were equivalent to that applied in clinical randomized studies, described as CC (cladribine + cyclophosphamide) and CMC (cladribine + mitoxantrone + cyclophosphamide) program, respectively (16-18).

\section{Materials and methods}

Patients. Fifty-two patients (30 men and 22 women) with B-CLL who had not received treatment previously, with a 
median leucocytosis of $41.1 \times 10^{9} / 1$ (ranging from 11.9 to $\left.300 \times 10^{9} / 1\right)$ were studied. B-CLL was diagnosed according to standard clinical and laboratory criteria (19). All patients were CD5, CD19, and CD23 positive and showed monoclonality for light chain immunoglobulin membrane surface receptors. The study was approved by the local ethics committee of Medical University of Lodz (No. RNN/237/ 03KE) and all the patients signed a consent form.

Cell preparation and incubation with chemotherapeutics. Freshly obtained peripheral blood was fractionated by Histopaque sedimentation. Non-adherent mononuclear cells were then resuspended in RPMI-1640 with $10 \%$ fetal calf serum supplemented with $2 \mathrm{mM}$ L-glutamine, $100 \mu \mathrm{g} / \mathrm{ml}$ streptomycin, $100 \mathrm{U} / \mathrm{ml}$ penicillin at a concentration of $2-5 \times 10^{6}$ cells/ $\mathrm{ml}$. Leukemic cells were incubated with $\operatorname{drug}(\mathrm{s})$ as specified at $37^{\circ} \mathrm{C}$ in an atmosphere of $5 \% \mathrm{CO}_{2}$ for $48 \mathrm{~h}$.

Drug concentration. Freshly isolated B-CLL cells were incubated with single agents or with drug combinations (applied simultaneously) for $48 \mathrm{~h}$. Pharmacological concentration of cladribine $(\mathrm{C} ; 0.05 \mu \mathrm{g} / \mathrm{ml})$, mafosfamide (Mf; $1 \mu \mathrm{g}$ / $\mathrm{ml})$, and mitoxantrone $(\mathrm{M} ; 0.5 \mu \mathrm{g} / \mathrm{ml})(13,20)$ was used. Simultaneously incubation of B-CLL cells with cladribine in combinations with mafosfamide (CMf) and mafosfamide + mitoxantrone (CMfM) was performed. Purine analog cladribine was obtained from Bioton (Poland). Anthracendione, mitoxantrone was purchased from Jelfa SA (Poland). Alkylating agent mafosfamide was kindly donated by Baxter Oncology GmbH (Germany).

Cell viability assay. B-CLL cells were plated onto 96-well multi-titre plates at a concentration of $5 \times 10^{5} /$ well in volume of $100 \mu \mathrm{l} /$ well. The cells were then incubated in the absence (control) or in the presence of either cladribine, mafosfamide, mitoxantrone alone or coincubated with cladribine and mafosfamide or mafosfamide + mitoxantrone. At the end of incubation, MTT (3-[4,5-dimethyltiazol-2-yl]-2,5-diphenyltetrazolium bromide) assay was carried out as described by Cole (21).

Cell lysates and Western blot analysis. After incubation with cladribine, mafosfamide, mitoxantrone or with combination of purine analog + mafosfamide or mafosfamide + mitoxantrone, cell lysates were prepared to assess the expression of proteins: procaspase-3, procaspase-9, polymerase poly(ADP-ribose) PARP-1, lamin B, Bax and Bcl-2. B-CLL cells were lysed $\left(4^{\circ} \mathrm{C} ; 20 \mathrm{~min}\right)$ in a buffer containing $10 \mathrm{mM}$ Tris- $\mathrm{HCl}(\mathrm{pH} 7.5)$, $300 \mathrm{mM} \mathrm{NaCl}, 1 \%$ Triton X-100, $2 \mathrm{mM} \mathrm{MgCl}_{2}, 0.1 \mathrm{M}$ DTT, and protease inhibitors added to a final concentration of $10 \mu \mathrm{M}$ and $1 \mathrm{mM}$ in the case of leupeptin, pepstatin A, benzamidine and phenylmethylsulfonyl fluoride, respectively. After the centrifugation at $20000 \mathrm{x}$ g for $15 \mathrm{~min}$, the supernatants were collected. Protein content was estimated by the method of Lowry et al (22). Lysates (50 $\mu \mathrm{g}$ of proteins) were electrophoretically separated by sodium dodecyl sulfate polyacrylamide gel electrophoresis (SDS-PAGE) on 11.2 or $8.0 \%$ gels (23) and transferred to Immobilon $\mathrm{P}$ according to Towbin et al (24). After blocking in 5\% nonfat dry milk and TBS (10 mM Tris-HCl, pH 7.5, $150 \mathrm{mM} \mathrm{NaCl)} \mathrm{for} 60 \mathrm{~min}$,

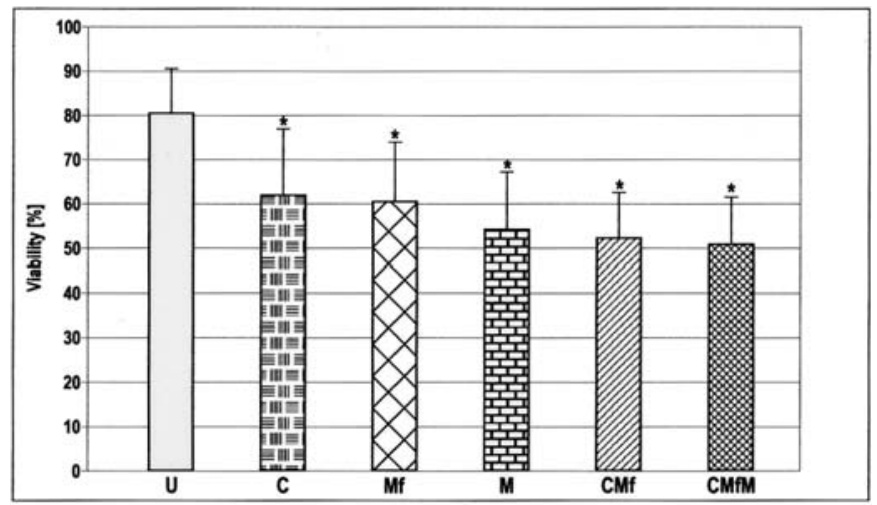

Figure 1. Cytotoxic effect of cladribine (C), mafosfamide (Mf), mitoxantrone (M), and cladribine combinations with mafosfamide (CMf) or mafosfamide + mitoxantrone (CMfM) on B-CLL cells. Cells were incubated at $37^{\circ} \mathrm{C}$ for $48 \mathrm{~h}$ without any agent (untreated; $\mathrm{U}$ ) or with test drugs as described in Materials and methods. Results are given as the mean value \pm SD; * $\mathrm{p}<0.0001$ versus untreated cells.

the membranes were incubated with antibodies specific to procaspases-3 and -9, nuclear proteins (PARP-1, lamin B1), Bcl-2 family members (Bax, Bcl-2), and actin in TBS in a cold room overnight. Rabbit or goat polyclonal antibodies (used at appropriate dilution) were purchased from Santa Cruz Biotechnology (USA). Subsequently, the membranes were washed several times in TBS containing $0.05 \%$ Tween-20 (TBST), and incubated with appropriate secondary antibodies conjugated with alkaline phosphatase (Sigma Chemical Co.) in TBS for $2 \mathrm{~h}$ at room temperature. The membranes were then washed several times with TBST, and the proteins were visualized by incubation with substrate solution $(0.33 \mathrm{mg} / \mathrm{ml}$ of nitro blue tetrazolium, $0.17 \mathrm{mg} / \mathrm{ml}$ of 5-bromo-4-chloro-3-indolyl phosphate in $100 \mathrm{mM}$ Tris- $\mathrm{HCl}, \mathrm{pH} 9.5,100 \mathrm{mM} \mathrm{NaCl}$ and $5 \mathrm{mM}$ $\mathrm{MgCl}_{2}$ ), prepared according to Leary et al (25).

The determination of $\mathrm{Bax} / \mathrm{Bcl}-2$ ratio was performed as described by Prokop et al (26). The integral density of immunostained polypeptide bands was estimated using the Gel-Pro Program. Control for the loading and transfer of protein samples was probed with actin antibodies.

DNA fragmentation. Assessment of DNA fragmentation was determined by slightly modified agarose gel electrophoresis prepared according to Bellosillo et al (27). Briefly, 5x10 B-CLL cells after washing with PBS (phosphate-buffered saline), were lysed for $20 \mathrm{~min}$ at $4^{\circ} \mathrm{C}$ in $5 \mathrm{mM}$ Tris- $\mathrm{HCl}, \mathrm{pH}$ $8.0,0.5 \%$ Triton $\mathrm{X}-100,20 \mathrm{mM}$ EDTA. After centrifugation at $12000 \mathrm{x} \mathrm{g}$ for $20 \mathrm{~min}$ the supernatant was treated with proteinase $\mathrm{K}(0.2 \mathrm{mg} / \mathrm{ml}$ in a buffer containing $10 \mathrm{mM}$ Tris$\mathrm{HCl}, \mathrm{pH} 8.0,150 \mathrm{mM} \mathrm{NaCl}, 40 \mathrm{mM}$ EDTA, 1\% SDS) for $6 \mathrm{~h}$ at $37^{\circ} \mathrm{C}$. DNA was extracted twice with buffered phenol/ chloroform/isoamyl alcohol (25:24:1), and precipitated with 0.1 volume of $3 \mathrm{M}$ sodium acetate and 2 volumes of ethanol at $-20^{\circ} \mathrm{C}$ overnight. DNA precipitates were washed twice with $75 \%$ ethanol, dissolved in triple-distilled water, and digested with RNase $(1 \mathrm{mg} / \mathrm{ml})$ for $2 \mathrm{~h}$ at $37^{\circ} \mathrm{C}$. Finally, DNA samples were electrophoresed by standard agarose gel (1.8\%) electrophoresis. Etidium bromide was used for DNA visualization under ultraviolet light. 


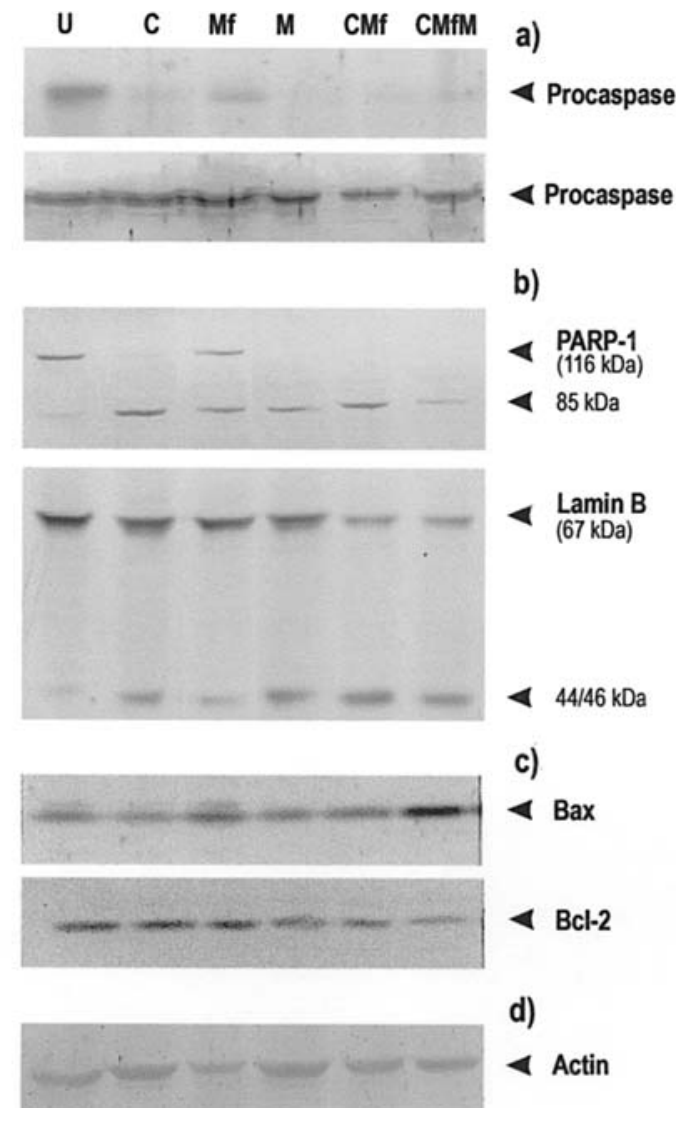

Figure 2. Expression of the apoptosis-related proteins. Lysates from untreated B-CLL cells (U) and cells exposed to cladribine (C), mafosfamide (Mf), mitoxantrone (M), combinations of cladribine with mafosfamide (CMf) or mafosfamide + mitoxantrone (CMfM) were separated by SDSPAGE and analyzed by Western blotting. Specific antibodies to caspase-3, -9 precursors (a); nuclear proteins: PARP-1, lamin B (b); Bcl-2 family members: Bax, Bcl-2 (c); and actin [loading control (d)] were used.

Cell fractionation. Fractionation of cells was performed using the digitonin method (28). Control and drug-treated cells, after washing twice with $\mathrm{PBS}$, were permeabilized for $1 \mathrm{~min}$ in ice-cold buffer $(50 \mu \mathrm{l})$ containing $1 \mathrm{mM} \mathrm{NaH} \mathrm{PO}_{4}, 8 \mathrm{mM}$ $\mathrm{Na}_{2} \mathrm{HPO}_{4}, 75 \mathrm{mM} \mathrm{NaCl}, 250 \mathrm{mM}$ sucrose, digitonin $(8.75 \mu \mathrm{g} /$ $10^{6}$ cells) and protease inhibitors at a concentration described in the section 'Cell lysates and Western blot analysis'. After centrifugation at $12000 \mathrm{x} \mathrm{g}$, the supernatant was removed as the cytosolic fraction. The pellet (organellar fraction) was resuspended in the above buffer (without digitonin). Supernatant and pellet fractions were supplemented with Laemmli sample buffer and boiled for $5 \mathrm{~min}$.

Bax protein oligomerization. Bax oligomer formation was analyzed after protein cross-link by glutaraldehyde according to the method developed by Ganju and Eastman (28), and immunoblotting. Cytosolic and organellar pellet fractions were obtained using digitonin lysis as described above. Glutaraldehyde solution (5\%) was then added to cell fractions to the final concentration of $0.3 \%$ aldehyde. Samples were incubated for $30 \mathrm{~min}$ at $25^{\circ} \mathrm{C}$. Reactions were stopped by the addition of Laemmli sample buffer and boiled for $5 \mathrm{~min}$. Samples were electrophoresed on $11.2 \%$ gels by the Laemmli method (23), and then analyzed by Western blotting using Bax antibody as the primary antibody.
Statistic analysis. The data of viability of untreated and drugtreated B-CLL cell samples were compared by ANOVA I and Tuckey's test. The Bax/Bcl-2 ratio values from untreated and treated leukemic cells were analyzed by ANOVA I test. The level of statistical significance was set at $\mathrm{p} \leq 0.05$.

\section{Results}

Cytotoxicity of cladribine and its combinations with mafosfamide and/or mitoxantrone. B-CLL cells freshly isolated from blood of 52 patients, with no prior therapy, were incubated for $48 \mathrm{~h}$ without or with cladribine (C), mafosfamide (Mf), mitoxantrone $(\mathrm{M})$ alone and with cladribine combinations with mafosfamide (CMf) or mafosfamide + mitoxantrone (CMfM). Treatment of leukemic cells with the drug(s) produced an inhibitory effect on their viability (Fig. 1). The data showed that the viability of untreated CLL cells was $80.4 \pm 10.0 \%$. Cladribine, mafosfamide and mitoxantrone added separately decreased viability of B-CLL cells up to mean values of $61.8 \pm 15.2 \%, 60.4 \pm 13.5 \%$ and $54.1 \pm 13.0 \%$ (versus untreated, $\mathrm{p}<0.0001$ ), respectively. The combinations of cladribine containing mafosfamide or mafosfamide + mitoxantrone induced an additional inhibitory effect in comparison with purine analog alone, i.e., $52.1 \pm 10.2 \%, 50.7 \pm 10.6 \%$ versus $61.8 \pm 15.2 \%(\mathrm{p}<0.001)$. The introduction of mitoxantrone alone to the studied cells caused reduction of their viability. However, the presence of this agent in the combination of cladribine + mafosfamide did not cause a significant decrease of cell viability (Fig. 1).

Influence of cladribine and its combinations with mafosfamide and/or mitoxantrone on expression of proteins associated with apoptosis. After incubation of B-CLL cells with cladribine, mafosfamide, mitoxantrone and combinations of cladribine with either mafosfamide or mafosfamide + mitoxantrone, cell lysates were probed by Western blotting, and expression of several proteins participating in realization of apoptosis was examined. Fig. 2 shows representative immunoblotting results of enzymes involved in apoptotic degradation of cellular proteins, i.e., precursors of caspase- 3 and caspase-9, two polypeptides, PARP-1 and lamin B, important for supporting of structural integrity and functional activity of cell nuclei as well as regulatory proteins belonging to Bcl-2 family, Bax and Bcl-2. Procaspase-9 (mol. wt. 46 kDa) - apical enzyme in mitochondrial pathway of apoptosis is activated through an apoptosome-induced conformational changes (29). In active form caspase- 9 processes the main apoptotic executioner, procaspase-3 (mol. wt. $32 \mathrm{kDa}$ ) and/or a caspase cascade leading to programmed death $(30,31)$.

Expression of procaspase-3 and -9, after exposure of BCLL cells to the drugs varied among the examined type of treatment. As shown in Fig. 2a, the expression of both procaspases in studied cells was the most sensitive to the combinations of cladribine with mafosfamide and/or mitoxantrone in comparison with untreated ones. Slight immunoreactivity of caspase-3 precursor was also noted after incubation with cladribine and mitoxantrone only.

Immunoblotting results of nuclear proteins, PARP-1 (mol. wt. $116 \mathrm{kDa}$ ) and lamin B (mol. wt. $67 \mathrm{kDa}$ ) in untreated and drug-treated cell lysates are presented in Fig. 2b. It is 


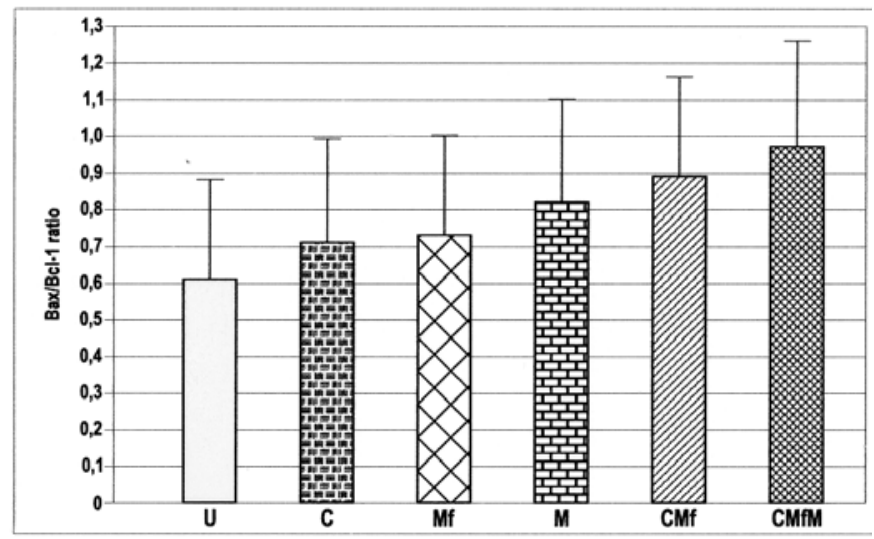

Figure 3. Comparison of Bax/Bcl-2 ratio values in untreated B-CLL cells (U) and cells exposed to cladribine (C), mafosfamide (Mf), mitoxantrone (M), combinations of cladribine with mafosfamide (CMf) or mafosfamide + mitoxantrone (CMfM). Bax and Bcl-2 expression was analyzed by Western blotting and subsequent videodensitometry. The $\mathrm{Bax} / \mathrm{Bcl}-2$ ratios were determined and mean values $\pm \mathrm{SD}$ are given $(\mathrm{p}=0.05)$.

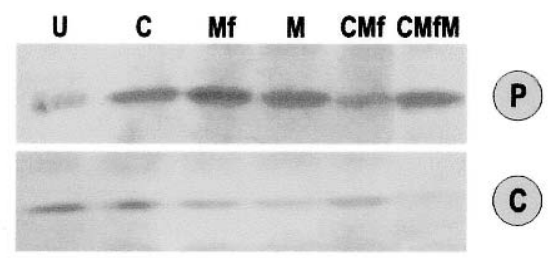

Figure 4. Translocation of Bax from the cytosol fraction to cellular pellet of untreated B-CLL cells (U) and cells exposed to cladribine (C), mafosfamide (Mf), mitoxantrone (M), combinations of cladribine with mafosfamide (CMf) or mafosfamide + mitoxantrone (CMfM). Samples were separated by SDS-PAGE, and probed with antibody to Bax by Western blotting.

described that during apoptosis PARP-1 is cleaved to 85 and $24 \mathrm{kDa}$ fragments (32), whereas lamin B to 46 and $24 \mathrm{kDa}$ polypeptides $(33,34)$. Results of our experiments demonstrated that in model cells subjected to treatment with drugs added alone or in 2- or 3-drug combinations, significant proteolysis of PARP-1 and lamin B was noted when compared to untreated cells. Full length of PARP-1 diminished or almost disappeared, and proteolytic product of $85 \mathrm{kDa}$ emerged. In the same conditions of incubation, B-CLL cells responded to the applied drugs cleaving another nuclear component, lamin B; however, with different efficiency. Strongly immunostained native lamin B in untreated leukemic cells decreased significantly, primarily in the samples exposed to cladribine combinations with mafosfamide and/or mitoxantrone. Proteolytic degradation of this nuclear protein was accompanied by the appearance of $44 / 46 \mathrm{kDa}$ fragment. Immunoblot analysis of procaspase- 3 and -9 as well as both nuclear proteins revealed that these molecules in B-CLL cells in vitro appear to be less sensitive to mafosfamide than cladribine and mitoxantrone alone. It is accepted that in cancer cells apoptotic death program is often regulated abnormally (35). A variety of stimuli including chemotherapeutics, mediate apoptosis via mitochondrial pathway which is mainly regulated by proteins belonging to the Bcl-2 family $(36,37)$. We observed that the level of proapoptotic Bax protein (mol. wt. $21 \mathrm{kDa}$ ) expression increased after incubation of B-CLL cells with

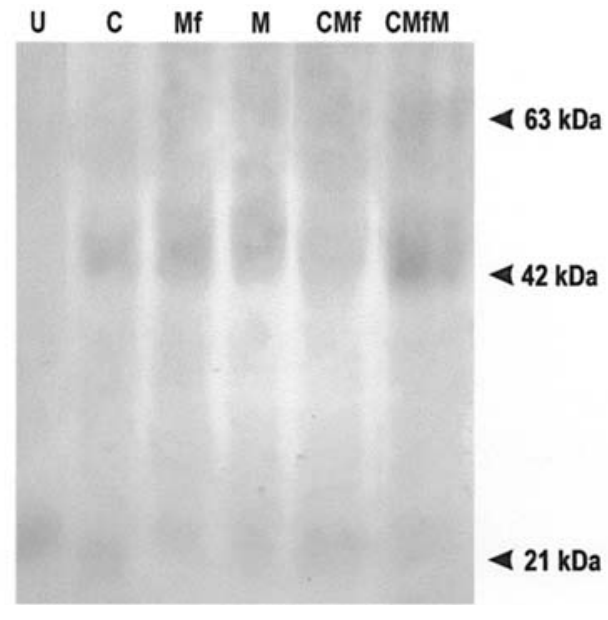

Figure 5. Bax oligomerization in B-CLL cells after exposure to cladribine (C), mafosfamide (Mf), mitoxantrone (M), combinations of cladribine with mafosfamide (CMf) or mafosfamide + mitoxantrone (CMfM). Cell lysates from untreated cells (U), and drug-treated cells were cross-linked with $0.3 \%$ glutaraldehyde and then separated by SDS-PAGE, and probed with antibody to Bax by Western blotting.

added drugs, however to a different degree. Cladribine combinations especially with mafosfamide + mitoxantrone induced the strongest effect on this protein level comparing with untreated cells (Fig. 2c). In the same cell samples treated with drugs added solely, antiapoptotic protein Bcl-2 (mol. wt. $26 \mathrm{kDa}$ ) declined slightly or moderately. Immunoreactivity of Bcl-2 clearly decreased in leukemic cells exposed to 3 drugs together. In our experiments the $\mathrm{Bax} / \mathrm{Bcl}-2$ ratio values in untreated and drug-treated B-CLL cells were compared. As shown in Fig. 3, this parameter was influenced by different drug treatments. The Bax/Bcl-2 ratios were $0.60 \pm 0.27$ and $0.71 \pm 0.28,0.73 \pm 0.27,0.82 \pm 0.30,0.89 \pm 0.27,0.97 \pm 0.25$ $(\mathrm{p}=0.05)$ in the lysates of leukemic cells incubated without any drugs and in samples treated with cladribine; mafosfamide; mitoxantrone; cladribine + mafosfamide; cladribine + mafosfamide + mitoxantrone, respectively.

Bax protein translocation. During apoptosis induced by chemotherapeutics Bax protein, which in vital cells resides as a monomer, is translocated from the cytosol to the mitochondria, where it oligomerizes $(35,38)$. Recently, endoplasmic reticulum-localization of Bax in vital cells has been reported (38). Detection of this protein with antibodies recognizing Bax was performed in cellular pellet and cytosolic fractions of the studied cells, separated by digitonin permeabilization. Different levels of Bax are accumulated in cellular pellet of B-CLL samples followed by incubation with drugs added solely, and in 2 or 3 drug combinations (Fig. 4). This translocation was accompanied by the decrease of described protein in the cytosol of drug-treated cells, and almost disappeared in those incubated with 3 drugs.

Bax oligomerization. Total lysates obtained by lysis with digitonin of untreated and drug-exposed B-CLL cells were cross-linked by $0.3 \%$ glutaraldehyde (28), and then probed by Western blotting. As shown in Fig. 5, Bax oligomer formation can be activated in leukemic cells after their incubation with 3 examined drugs added alone, and particularly 


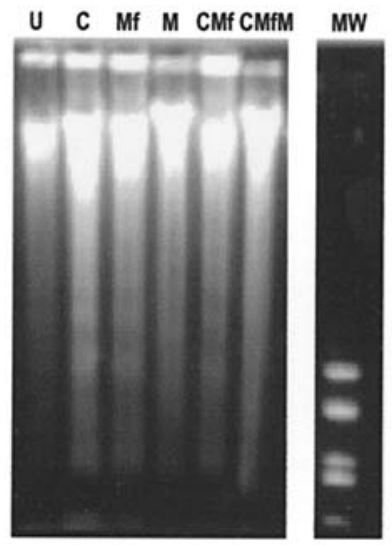

Figure 6. Induction of DNA fragmentation in untreated B-CLL cells (U) and cells exposed to cladribine (C), mafosfamide (Mf), mitoxantrone (M), combinations of cladribine with mafosfamide (CMf) or mafosfamide + mitoxantrone (CMfM). DNA fragments were analyzed by agarose gel electrophoresis; MW, molecular weight marker (pUC 18DNA Hae III digest).

intensive in the case of samples with cladribine introduced together with mafosfamide + mitoxantrone. B-CLL cells incubated without any drug(s) did not form oligomers.

DNA fragmentation. To determine whether the cytotoxicity of B-CLL cells was due to apoptosis induction, we examined if their treatment with the drugs applied solely or with 2- and 3-drug combinations induced DNA fragmentation. In electropherograms of DNA samples isolated from leukemic cells that underwent drug-exposure, extensive oligonucleosomal fragmentation induced by tested drug(s) was observed, but not in control untreated cells (Fig. 6).

\section{Discussion}

Failure to induce apoptosis, the evolutionary conserved process of programmed death is a critical phenomenon in the development of many cancers, including B-CLL (39-41). Since the reasons for apoptosis inhibition are still unclear a large number of studies have been performed to evaluate the relations between drug-induced cytotoxicity of malignant cells and the events accompanying cell programmed death. It is postulated that activation of apoptosis by cytotoxic agents is a mechanism by which cancer cells are forced to undergo cell death (42).

Our in vitro study focused on estimation of chemosensitivity of B-CLL cells exposed to cladribine alone and in combinations with mafosfamide and/or mitoxantrone. The treatment of leukemic cells was carried out with agents analogous to the applied randomized clinical program based on cladribine in monotherapy (C), and combined with cyclophosphamide (CC) or mitoxantrone + cyclophosphamide (CMC) $(17,18)$. Moreover, we investigated the influence on leukemic cells mafosfamide and mitoxantrone, components of the used drug-combinations. All examined samples were sensitive to the applied drugs; however, to a different extent, comparing with untreated (control) cells. The viability of BCLL cells decreased significantly after incubation with combinations of cladribine containing mafosfamide and/or mitoxantrone. The cytosolic effect of mitoxantrone was greater than cladribine or mafosfamide alone. The drugs, besides the inhibition of B-CLL cell viability, induced some events characteristic of apoptosis. A variety of stimuli, including cytotoxic drugs, mediate cancer cell programmed death by influencing key effector/regulator proteins associated with apoptosis and fragmentation of genetic material (43). The exposure of leukemic cells to the drugs alone and cladribine in combinations with mafosfamide and/or mitoxantrone affected the changes in expression/proteolysis of chosen apoptosis-related proteins, including caspase-3 and -9 precursors, nuclear proteins (PARP-1, lamin B), and two members of $\mathrm{Bcl}-2$ family regulators ( $\mathrm{Bax}, \mathrm{Bcl}-2)$. The expression of the above polypeptides in drug-treated leukemic cells changed to a different degree depending on the treatment type. The marked lower expression/proteolysis of caspase-3, -9 precursors as well as both nuclear proteins was particularly observed in B-CLL cells exposed to cladribine combined with mafosfamide and/or mitoxantrone. The level of PARP-1 and lamin B expression also significantly declined with a concomitant increase of 85 and $44 / 46 \mathrm{kDa}$ degradation fragments, respectively, in the case of samples treated with mitoxantrone and cladribine only. The appearance of PARP-1 and lamin $\mathrm{B}$ degradation products appear to be caused by caspases (mainly caspase-3) $(32,33,44)$. The level of both procaspases and nuclear proteins slightly changed after mafosfamide treatment.

At present it is accepted that caspases (cysteinyl proteases) play an essential role in proteolytic degradation during apoptosis $(36,45)$. Some of these enzymes can cleave and inactivate cytosolic and organellar proteins important for cell survival (30). A characteristic feature of programmed death is the marked change in cell nuclei, which reflect proteolytic degradation of some nuclear proteins and DNA fragmentation $(43,46)$. It was demonstrated that caspase- 3 is involved in activation of endonuclease - CAD - responsible for the oligonucleosomal DNA fragmentation (47). Among the nuclear proteins, PARP-1 and lamins, which are caspases substrates, have received significant attention in apoptosis studies. PARP-1 synthesizes poly(ADP-ribose) from NAD in response to DNA strand breaks and participates in many processes including DNA replication, DNA repair, and genome stability (48). This enzyme was the first nuclear protein to be cleaved by caspases (32). Lamin B, DNA-binding protein is a member of the lamin family. It is an important component of nuclear lamina, a filamentous network which stabilizes cell nuclei, and also plays a role in DNA replication and chromatin organization (49). Proteolytic degradation of lamin B by caspase-3 $(33,34)$, and other lamins (A and C) by caspase-6 (50) facilitates the detachment of nuclear envelope from chromatin and the clustering of nuclear complexes, important signs of apoptosis (51).

There is growing evidence that expression of Bcl-2 family proteins also represents an important determinant in cell susceptibility to apoptotic stimuli $(35,38)$. This family contains proapoptotic [(Bax-like death factors) and Bcl-2 factors described as BH3 only], and antiapoptotic members (Bcl-2like factors) - which protect cells from death. Upon apoptosis induction proapoptotic proteins (e.g. Bax) can bind to anti-apoptotic ones (e.g. Bcl-2) and remove the negative 
regulation on the apoptosome, resulting in procaspase activation and induction of an intrinsic, mitochondrial pathway $(37,38)$. Bax and Bcl-2 may homo- or heterodimerize with one another, thereby antagonize or enhance the function of one another. Published reports suggest, that $\mathrm{Bax} / \mathrm{Bcl}-2$ ratio plays a role in setting the susceptibility of cells to apoptotic signals $(52,53)$.

In B-CLL cells which underwent incubation with examined drugs alone or in combinations of cladribine with mafosfamide and/or mitoxantrone low/moderate decrease of antiapoptotic factor, Bcl-2 was noted. In the same cell samples the expression of proapoptotic protein Bax increased moderately. The elevation of this apoptotic promoter reached the highest level in leukemia cells treated with cladribine + mafosfamide + mitoxantrone. Consequently, the highest $\mathrm{Bax} / \mathrm{Bcl}-2$ ratio was determined among B-CLL samples exposed to 3 drugs together. The obtained results also showed that the tested drugs, primarily cladribine combined with mafosfamide and mitoxantrone enhanced some apoptotic events related to the mitochondrial pathway. Proteolytic cleavage of caspase-9 and -3 precursors, increase of $\mathrm{Bax} / \mathrm{Bcl}-2$ ratios, translocation of Bax protein from cytosolic fraction to cellular pellet containing mitochondria, where this polypeptide revealed capacity to form oligomers were observed. The changes in leukemic cells exposed to the drugs were accompanied by DNA fragmentation.

B-CLL is a heterogeneous, incurable disease, however, new therapeutic strategies are being developed. Cladribine displays significant activity in cancer arising from the clonal expansion of B cells, mainly by modulation of apoptosis pathways $(10,20,54,55)$. Our findings demonstrate that the combination of this purine analog with mafosfamide and/or mitoxantrone is more efficacious in inhibiting B-CLL cell growth and in inducing apoptosis than any of the drugs alone.

\section{Acknowledgements}

This work was supported partially by Grant No. 505/362 from University of Lodz and by the Polish State Committee of Science Grant No. 2P05B01828.

\section{References}

1. Gale RP, Caligaris-Cappio F, Dighiero G, Keating M, Montserrat E and Rai K: Recent progress in chronic lymphocytic leukemia. International Workshop on Chronic Lymphocytic Leukemia. Leukemia 8: 1610-1614, 1994.

2. Caligaris-Cappio F: Role of the microenvironment in chronic lymphocytic leukaemia. Br J Haematol 123: 380-388, 2003.

3. Defrance T, Casamayor-Palleja M and Krammer PH: The life and death of a B cell. Adv Cancer Res 86: 195-225, 2002.

4. Rai KR: Cladribine for the treatment of hairy cell leukemia and chronic lymphocytic leukemia. Semin Oncol 25 (Suppl 7): 19-22, 1998.

5. Rai KR, Peterson BL, Appelbaum FR, et al: Fludarabine compared with chlorambucil as primary therapy for chronic lymphocytic leukemia. N Engl J Med 343: 1750-1757, 2000.

6. Nabhan C, Gartenhaus RB and Tallman MS: Purine nucleoside analogues and combination therapies in B-cell chronic lymphocytic leukemia: dawn of a new era. Leuk Res 28: 429-442, 2004.

7. Keating MJ: Chronic lymphocytic leukemia. Semin Oncol 26: 107-114, 1999.

8. Gandhi V and Plunkett W: Combination strategies for purine nucleoside analogs. In: Chronic Lymphoid Leukemias. Cheson BD (ed). Marcel Dekker, Inc., Basel, New York, pp195-208, 2001.
9. Robak T: Therapy of chronic lymphocytic leukemia with purine analogs and monoclonal antibodies. Transfus Apher Sci 32: 33-44, 2005.

10. Robertson LE, Chubb S, Meyn RE, Story M, Ford R, Hittelman WN and Plunkett W: Induction of apoptotic cell death in chronic lymphocytic leukemia by 2-chloro-2'-deoxyadenosine and 9-beta-D-arabinosyl-2-fluoroadenine. Blood 81: 143-150, 1993.

11. Van den Neste E, Cardoen S, Offner F and Bontemps F: Old and new insights into the mechanisms of action of two nucleoside analogs active in lymphoid malignancies: fludarabine and cladribine. Int J Oncol 27: 1113-1124, 2005.

12. McConkey DJ, Chandra J, Wright S, Plunkett W, McDonnell TJ, Reed JC and Keating M: Apoptosis sensitivity in chronic lymphocytic leukemia is determined by endogenous endonuclease content and relative expression of BCL-2 and BAX. J Immunol 156: 2624-2630, 1996.

13. Bellosillo B, Villamor N, Colomer D, Pons G, Montserrat E and Gil J: In vitro evaluation of fludarabine in combination with cyclophosphamide and/or mitoxantrone in B-cell chronic lymphocytic leukemia. Blood 94: 2836-2843, 1999.

14. Chow KU, Rummel MJ, Weidmann E, et al: Induction of apoptosis by 2-chloro-2'-deoxyadenosine (2-CdA) alone and in combination with other cytotoxic drugs: synergistic effects on normal and neoplastic lymphocytes by addition of doxorubicin and mitoxantrone. Leuk Lymph 36: 559-567, 2000.

15. Robak T, Blonski JZ, Kasznicki M, et al: Cladribine with prednisone versus chlorambucil with prednisone as first-line therapy in chronic lymphocytic leukemia: report of a prospective, randomized, multicenter trial. Blood 96: 2723-2729, 2000.

16. Robak T, Blonski JZ, Kasznicki M, et al: Cladribine combined with cyclophosphamide and mitoxantrone as front-line therapy in B-cell chronic lymphocytic leukemia. Leukemia 15: 1510-1516, 2001.

17. Kobylinska A, Blonski JZ, Hanausek M, et al: Determination of the in vivo effects of cladribine alone and its combination with cyclophosphamide or cyclophosphamide and mitoxantrone on Bax and Bcl-2 protein expression in B-CLL cells. Oncol Rep 11: 699-705, 2004.

18. Robak T, Blonski JZ, Gora-Tybor J, et al: Cladribine alone and in combination with cyclophosphamide plus mitoxantrone in the treatment of progressive chronic lymphocytic leukemia: report of prospective, multicenter, randomized trial of the Polish Adult Leukemia Group (PALG CLL2). Blood 108: 473-479, 2006 (Epub March 21, 2006)

19. Cheson BD, Bennett JM, Grever M, Kay N, Keating MJ, O'Brien S and Rai KR: National Cancer Institute - sponsored Working Group guidelines for chronic lymphocytic leukemia: revised guidelines for diagnosis and treatment. Blood 87 : 4990-4997, 1996

20. Castejon R, Vargas JA, Briz M, Berrocal E, Gea-Banacloche JC, Romero Y, Fernandez MN and Durantez A: Induction of apoptosis by 2-chlorodeoxyadenosine in B cell chronic lymphocytic leukemia. Leukemia 11: 1253-1257, 1997.

21. Cole SPC: Rapid chemosensitivity testing of human lung tumor cells using the MTT assay. Cancer Chemother Pharmacol 17: 259-263, 1986.

22. Lowry OH, Rosebrough NJ and Farr AL: Protein measurement with the Folin phenol reagent. J Biol Chem 193: 265-275, 1951.

23. Laemmli UK: Cleavage of structural proteins during the assembly of the head of bacteriophage T4. Nature 227: 680-685, 1970.

24. Towbin H, Staechlin T and Gordon J: Electrophoretic transfer of protein from polyacrylamide gels to nitrocellulose sheets: procedure and some applications. Proc Natl Acad Sci USA 76: 4350-4354, 1979.

25. Leary JJ, Brigati JJ and Ward DC: Rapid biotin labelled DNA probes hybrized to DNA or RNA immobilized on nitrocellulose: Bio-blots. Proc Natl Acad Sci USA 80: 4045-4049, 1983.

26. Prokop A, Wieder T, Sturm I, et al: Relapse in childhood acute lymphoblastic leukemia is associated with a decrease of the Bax/ Bcl-2 ratio and loss of spontanous caspase-3 processing in vivo. Leukemia 14: 1606-1613, 2000.

27. Bellosillo B, Pique M, Barragan M, et al: Aspirin and salicytate induce apoptosis and activation of caspases in B-cell chronic lymphocytic leukemia cells. Blood 92: 1406-1414, 1998.

28. Ganju N and Eastman A: Zinc inhibits Bax and Bak activation and cytochrome c release induced by chemical inducers of apoptosis but not by death-receptor-initiated pathways. Cell Death Differ 10: 652-661, 2003. 
29. Li P, Nijhawan D, Budihardjo I, Srinivasula SM, Ahmad M, Alnemri ES and Wang X: Cytochrome c and dATP-dependent formation of Apaf-1/caspase-9 complex initiates an apoptotic protease cascade. Cell 91: 479-489, 1997.

30. Degterev A, Boyce M and Yuan J: A decade of caspases. Oncogene 22: 8543-8567, 2003.

31. Hill MM, Adrian C and Martin SJ: Portrait of a killer: the mitochondrial apoptosome emerges from the shadows. Mol Interv 3: 19-26, 2003.

32. Lazebnik YA, Kaufmann SH, Desnoyers S, Poirier GG and Earnshaw WC: Cleavage of poly(ADP-ribose)polymerase by a proteinase with properties like ICE. Nature 371: 346-347, 1994.

33. Slee EA, Adrain C and Martin SJ: Executioner caspase-3, -6, and -7 perform distinct, non-redundant roles during the demolition phase of apoptosis. J Biol Chem 276: 7320-7326, 2001.

34. Kivinen K, Kallajoki M and Taimen P: Caspase- 3 is required in the apoptotic disintegration of the nuclear matrix. Exp Cell Res 311: 62-73, 2005.

35. Cory S, Huang DC and Adams JM: The Bcl-2 family: roles in cell survival and oncogenesis. Oncogene 22: 8590-8607, 2003.

36. Hengartner MO: The biochemistry of apoptosis. Nature 407: 770-776, 2000

37. Borner C: The Bcl-2 protein family: sensors and checkpoints for life-or-death decisions. Mol Immunol 39: 615-647, 2003.

38. Schinzel A, Kaufmann T and Borner C: Bcl-2 family members: intracellular targeting, membrane-insertion, and changes in subcellular localization. Biochim Biophys Acta 1644: 95-105, 2004.

39. Kitada S, Andersen J, Akar S, et al: Expression of apoptosisregulating proteins in chronic lymphocytic leukemia: correlations with in vitro and in vivo chemoresponses. Blood 91: 3379-3389, 1998.

40. Lowe SM and Lin AW: Apoptosis in cancer. Carcinogenesis 21: 485-495, 2000

41. Ringhausen I, Schneller F, Bogner C, et al: Constitutively activated phosphatidylinositol-3 kinase (PI-3K) is involved in the defect of apoptosis in B-CLL association with protein kinase Co. Blood 100: 3741-3748, 2002.

42. Cummings J, Ward TH, Ranson M and Dive C: Apoptosis pathway-targeted drugs from the bench to the clinic. Biochim Biophys Acta 1705: 53-66, 2004.

43. Robertson JD, Orrenius S and Zhivotovsky B: Nuclear events in apoptosis. J Struct Biol 129: 346-358, 2000.
44. Tewari M, Quan LT, O'Rourke K, et al: Yama/CPP32 beta, a mammalian homolog of CED-3, is a CrmA-inhibitable protease that cleaves the death substrate poly(ADP-ribose) polymerase. Cell 81: 801-809, 1995.

45. Chang YH and Yang H: Proteases for cell suicide: functions and regulation of caspases. Microbiol Mol Biol Rev 64: 821-846, 2000.

46. Dynlacht JR, Roberts ZV, Earles M, Henthorn J and Seno JD Different patterns of DNA fragmentation and degradation of nuclear matrix proteins during apoptosis induced by radiation, hyperthermia or etoposide. Radiat Res 154: 515-530, 2000.

47. Enari M, Sakahira H, Yokoyama H, Okawa K, Iwamatsu A and Nagata S: A caspase-activated DNase that degrades DNA during apoptosis and its inhibitor ICAD. Nature 391: 43-50, 1998.

48. Herzeg Z and Wang Z-Q: Function of poly(ADP-ribose) polymerase (PARP) in DNA repair, genomic integrity and cell death. Mutation Res 477: 97-110, 2001.

49. Stuurman N, Heins S and Aebi U: Nuclear lamins: their structure, assembly, and interactions. J Struct Biol 122: 42-66, 1998.

50. Rao L, Perez D and White E: Lamin proteolysis facilitates nuclear events during apoptosis. J Cell Biol 135: 1441-1455, 1996.

51. Buenida B, Santa-Maria A and Courvalin JC: Caspase-dependent proteolysis of integral and peripheral proteins of nuclear membranes and nuclear pore complex proteins during apoptosis. J Cell Sci 112: 1743-1753, 1999.

52. Oltvai $\mathrm{Z}$ and Korsmayer S: Bcl-2 heterodimerizes in vivo with conserved homolog, Bax, that accelerates programmed cell death. Cell 74: 609-619, 1993.

53. Pepper C, Hoy T and Bentley DP: Bcl-2/Bax ratios in chronic lymphocytic leukemia and their correlation with in vitro apoptosis and clinical resistance. Br J Cancer 76: 935-958, 1997.

54. Genini D, Adachi S, Chao Q, et al: Deoxyadenosine analogs induced programmed cell death in chronic lymphocytic leukemia by damaging the DNA and by directly affecting the mitochondria. Blood 96: 3537-3543, 2002.

55. Marzo J, Perez-Galan P, Giraldo P, Rubio-Felix D, Anel A and Naval J: Cladribine induces apoptosis in human leukaemia cells by caspase-dependent and -independent pathways acting on mitochondria. Biochem J 359: 537-546, 2001. 